\title{
High temperature stability of n-decanethiol by adsorption on nickel powders used as reforming catalysts in solid oxide fuel cells (SOFC)
}

\author{
H. Oudghiri-Hassani ${ }^{1}$, N. Abatzoglou ${ }^{1}$, S. Rakass ${ }^{1}$ \& P. Rowntree ${ }^{2}$ \\ ${ }^{I}$ Department of Chemical Engineering, Université de Sherbrooke, \\ Quebec, Canada \\ ${ }^{2}$ University of Guelph, Surface Chemistry and Dynamics Laboratory, \\ Department of Chemistry, Ontario, Canada
}

\begin{abstract}
Solid Oxide Fuel Cells (SOFC) are among the most promising electricity producing technologies. Their successful implementation and versatility depends upon a number of still not fully solved technological issues; namely, the possibility of using both fossil and renewable energy vectors is one of the most significant. Such energy vectors, constituting a crucial SOFC feedstock, are the natural gas, the biogas and all forms of fossil and renewable liquid fuels like diesel, biodiesel, "green" diesel. These fuels require a conversion step because SOFC can use only $\mathrm{H}_{2}$ and $\mathrm{CO}$. This conversion step is achieved through catalytic reforming and/or partial oxidation. The most successful catalysts are ceramic-supported bimetallic composites. The presence of sulphur in the fuels is detrimental to the catalysts and constitutes one of the basic hurdles in scaling-up and adopting commercially these conversion technologies.

In this paper, the authors, based on their previous work on the role of sulphur on micronic Ni powders used as $\mathrm{CH}_{4}$ reforming catalysts, study the behaviour of medium size thiols adsorbed at the surface of the Ni powders and treated thermally in a differential reactor set-up. The Diffuse Reflectance Infra-red Fourier Transform Spectroscopy (DRIFTS) analyses before and after adsorption and thermal treatments have shown that these Ni surfaces stabilize the adsorbed hydrocarbon chains and alter their catalytic properties during reforming. These results are quite surprising and open the field to a positive synergy between surface chemists and engineers in an effort to better control the efficiency and improve the tolerance to sulphur of these reforming catalysts.

Keywords: renewable and fossil energy, $\mathrm{SOFC}, \mathrm{CH}_{4}, \mathrm{Ni}$, reforming, Thiols, adsorption, stability, DRIFT.
\end{abstract}




\section{Introduction}

Materials containing organic-inorganic interfaces usually display a combination of molecular and solid-state properties. These are of interest for applications ranging from chemical sensing [1] to microelectronics [2] and catalysis [3]. Thiols - organic compounds carrying a SH group - are widely used to anchor organic layers to gold surfaces [4], because gold is catalytically sufficiently active to replace relatively weak $\mathrm{S}-\mathrm{H}$ bonds with $\mathrm{Au}-\mathrm{S}$ bonds, yet is too inert to attack $\mathrm{C}-\mathrm{C}$ and $\mathrm{C}-\mathrm{H}$ bonds present in the organic layer. This chemical activity can, thus, be used to obtain with relative ease high-quality monolayers from a large variety of organothiols solutions $[4,5]$. These organic layers can, in principle, be formed on the surfaces of various metals capable of creating strong $\mathrm{C}$-Me bonds. Nevertheless, such surfaces are able to catalyze the decomposition of organic layers at onset temperatures between 130 to $330^{\circ} \mathrm{C}$, through a progressive $\mathrm{C}-\mathrm{H}$ and $\mathrm{C}-\mathrm{C}$ bond breaking mechanism [6]. Motivated by the high potential for applications of self-assembling monolayers (SAMs), the more reactive metals such as iron [7], nickel [8], zinc [9], and some alloys [10] have become potential substrates of growing interest. However, their surface modification processing is more challenging and requires not only specific preparation procedures but also a good understanding and control of the modification mechanisms also. This work brings experimental proofs that selfassembled monolayers (SAMs) of n-decanethiol, adsorbed on nickel powder, are thermally stable and that the kinetics of their pyrolysis is slow at temperatures below $1000^{\circ} \mathrm{C}$. Thus, the process could eventually be used to create a wide range of exceptionally stable organic layers on nickel powder particles.

\section{Experimental: materials and methods}

Experiments have been performed using a pure nickel powder (SBET $=0.44 \mathrm{~m}^{2} / \mathrm{g}$, particle size range of $1-20 \mu \mathrm{m}$ ) with an open filamentary structure and irregular spiky surface texture. The powder is supplied by Inco (Inco Ni 255). n-decanethiol adsorbed on this nickel powder was obtained by immersion of the pristine nickel powder in $10^{-3} \mathrm{M}$ solutions of $\mathrm{n}$-decanethiol/methanol; these solutions were containing excess thiol (by several orders of magnitude) as compared to the monolayer quantities deposited. The immersion time was $\sim 20$ hours. Following the immersion process, the treated samples were rinsed in copious quantities of fresh methanol. Finally, the samples were dried for 12 hours and then employed for their characterization tests.

\section{Results and discussion}

Figure 1(a) presents representative infrared spectra of n-decanethiol adsorbed on $\mathrm{Ni}$ recorded at four different temperatures, $23,700,1030$, and $1050^{\circ} \mathrm{C}$. All spectra were measured at ambient temperature. The data recorded at $23^{\circ} \mathrm{C}$ show the presence of the diagnostic $\mathrm{C}-\mathrm{H}$ stretching bands, as characterized by (i) the $\mathrm{d}+$ band $\left(\sim 2850 \mathrm{~cm}^{-1}\right)$, associated with the symmetric vibration of the $\mathrm{CH}_{2}$ units 
of the backbone chain, (ii) the $\mathrm{d}$ - band $\left(\sim 2918 \mathrm{~cm}^{-1}\right)$, associated with the antisymmetric vibration of the backbone chain $\mathrm{CH}_{2}$ units of the backbone chain, (iii) the Fermi-resonance influenced $\mathrm{r}_{\mathrm{FR}}{ }^{+}$band $\left(\sim 2930 \mathrm{~cm}^{-1}\right)$, associated with symmetric vibrations of the terminal $\mathrm{CH}_{3}$ groups, and (iv) the $\mathrm{r}^{-}$band $\left(\sim 2955 \mathrm{~cm}^{-1}\right)$, associated with antisymmetric vibrations of the terminal $\mathrm{CH}_{3}$ groups) [11]. The relative intensities of these various bands, their peak positions, and the peaks widths are remarkably similar to those of the alkanethiol monolayers, as adsorbed on planar $\mathrm{Au}(111)$ substrates [11] suggesting that the local environment of these adsorbates on the Ni surface is a rather well ordered one, despite the long-range disorder implicit in the use of powdered surface substrates. None of the spectra of the thiol-contaminated Ni powders exhibited significant intensity in the $\mathrm{r}+$ band $\left(\sim 2875 \mathrm{~cm}^{-1}\right)$, which is associated with the symmetric stretching mode of the terminal methyl groups. This result is similar to that obtained in the study of self-assembled monolayers, formed on metallic nanoparticules [12], which also show the absence of the $\mathrm{r}^{+}$band $\left(\sim 2875 \mathrm{~cm}^{-1}\right)$. By annealing to $700^{\circ} \mathrm{C}$ and by leaving it for 13 hours at this temperature under Ar carrier gas, the spectral data show the presence of all those bands observed earlier at $23^{\circ} \mathrm{C}$. By continuing the heating up to $1030^{\circ} \mathrm{C}$ under Ar carrier gas, the recovered data show the presence of all bands previously observed at $23^{\circ}$ and $700^{\circ} \mathrm{C}$, in addition to a new band that appears at $3060 \mathrm{~cm}^{-1}$, which can be attributed to the $\mathrm{C}-\mathrm{H}$ bond of olefins or aromatic compounds [13]. However, all of these bands disappear when the temperature of heating rises to $1050^{\circ} \mathrm{C}$ and is maintained at this level during 6 hours under Ar carrier gas. These results demonstrate the high thermal stability of the alkanethiolate SAMs adsorbed on $\mathrm{Ni}$, while the data found in the literature relative to the thermal stability of selfassembled monolayers on reactive metals show a quite opposite behavior. Thus, Nuzzo et al. [22, 23] have performed temperature-programmed desorption of methanethiolate SAMs on gold and reported a desorption maximum at $\sim 220^{\circ} \mathrm{C}$ [14]. Jaffey and Madix performed detailed mass spectroscopic studies of 2-methylpropanethiolate monolayers on gold and reported maximum desorption at $\sim 200^{\circ} \mathrm{C}$ [15]. Through the use of radiolabeled hexadecanethiolate monolayers, the complete loss of surface sulfur at $210^{\circ} \mathrm{C}$ was observed, with some loss occurring at as low as $100^{\circ} \mathrm{C}$ [16]. Similarly, Lai et al. [17] have reported that the decomposition of alkanethiols ( $\mathrm{RSH}$ with $\mathrm{R}=\mathrm{CH}_{3}, \mathrm{C}_{2} \mathrm{H}_{5}$, and $\mathrm{C}_{4} \mathrm{H}_{9}$ ) on a $\mathrm{Cu}$ (110) surface reaches a maximum rate at $70^{\circ} \mathrm{C}$. They also reported that the same alkanethiols, when adsorbed on a $\mathrm{Pt}(111)$ surface, also decomposed at a temperature below $100^{\circ} \mathrm{C}[18]$.

Figure 1(b) presents the DRIFTS analysis at lower frequencies. These data show the existence of significant surface modifications occurring during thermal treatment at different temperatures. An analysis of the possible assignment of the individual absorption bands to the corresponding bond configuration was undertaken and the results are presented below. Table 1 enables a comparison of spectra observed at different temperatures, along with their assignments. In large agreement with the literature data, $[19,20,21,24,26]$ we are able to draw the following conclusions: 


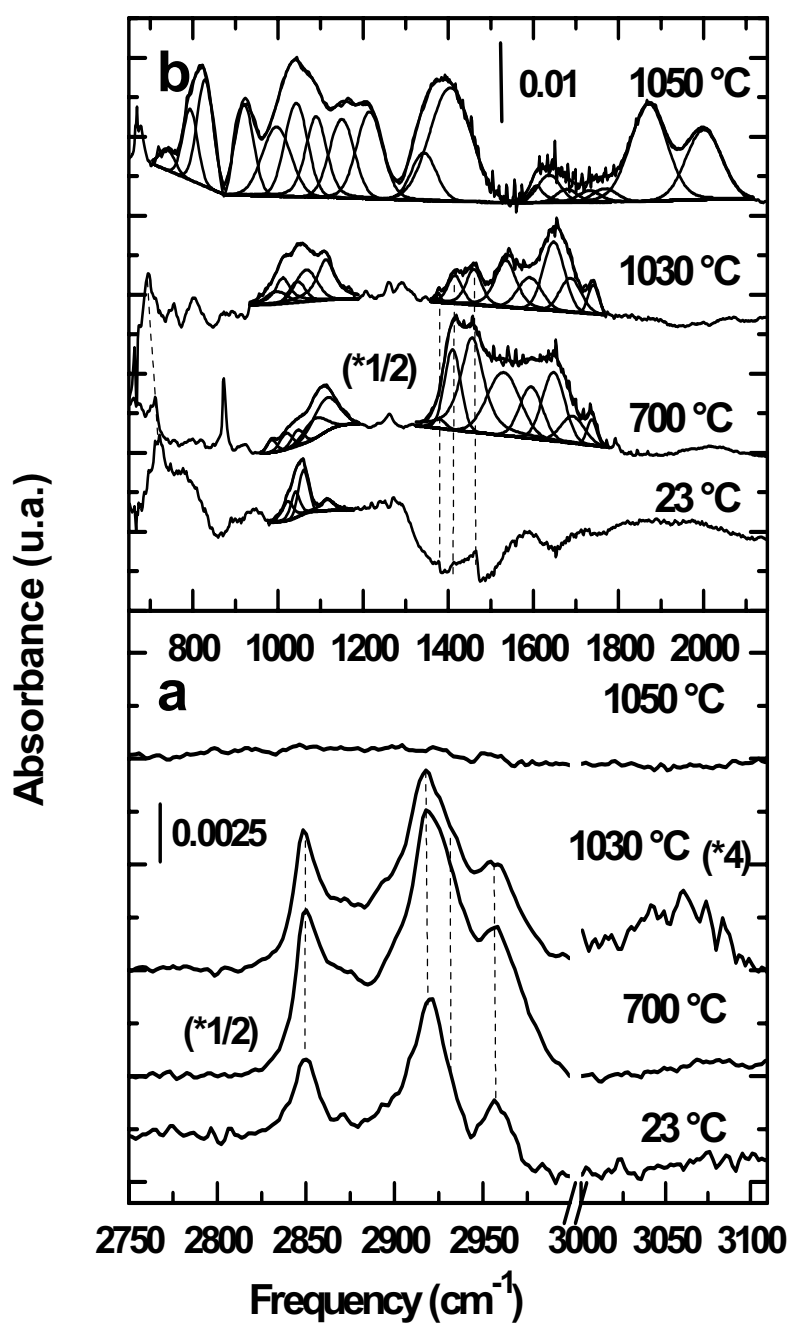

Figure 1: $\quad$ DRIFTS spectra of $n$-decanethiol adsorbed on Ni recorded at four different temperatures, $23^{\circ}, 700^{\circ}, 1030^{\circ}$, and $1050^{\circ} \mathrm{C}$ a) at high frequency and b) at low frequency.

(1) The spectrum recorded at $23^{\circ} \mathrm{C}$ shows the presence of bands characteristic of $\mathrm{n}$-decanethiol adsorption on $\mathrm{Ni}\left(v(\mathrm{C}-\mathrm{S}), \delta\left(\mathrm{CH}_{2}\right)\right.$, and $\left.\delta\left(\mathrm{CH}_{3}\right)\right)$ and the presence of sulfonates $\left(v\left(\mathrm{SO}_{4}\right)\right)$ (XPS data presented in the literature19 also show the presence of sulfonates).

(2) The spectrum recorded of the samples treated at $700^{\circ} \mathrm{C}$ (exposure of 13 hours at this temperature) and $1030^{\circ} \mathrm{C}$ shows, besides bands observed at $23^{\circ} \mathrm{C}$, the appearance of new bands corresponding to chemical species containing the groups $\mathrm{C}=\mathrm{C},-\mathrm{C}=\mathrm{C}=\mathrm{CH}_{2},>\mathrm{C}=\mathrm{C}=\mathrm{CH}_{2}$, and aromatic ring [20, 21, 24, 25 ]. 
(3) When these surfaces are thermally treated under $\mathrm{Ar}$ carrier gas at $1050^{\circ} \mathrm{C}$ over 6 hours, all previous bands characteristic of the adsorption of n-decanethiol on $\mathrm{Ni}$ disappear, and other bands, corresponding to characteristic groups in olefinic or aromatics, or both, compounds [20, 21, 24, 26] appear.

Table 1: Major peaks positions in 660-2150 $\mathrm{cm}^{-1}$ absorption band of n-decanethiol adsorbed on $\mathrm{Ni}$ recorded at four different temperatures, $23^{\circ}, 700^{\circ}, 1030^{\circ}$, and $1050^{\circ} \mathrm{C}$.

\begin{tabular}{|c|c|c|c|c|c|}
\hline $\begin{array}{c}\mathrm{Ni}-\mathrm{C}_{10} \mathrm{~S} \text { at } \\
23^{\circ} \mathrm{C}\end{array}$ & $\begin{array}{c}\mathrm{Ni}-\mathrm{C}_{10} \mathrm{~S} \text { at } \\
700^{\circ} \mathrm{C}\end{array}$ & $\begin{array}{c}\mathrm{Ni}-\mathrm{C}_{10} \mathrm{~S} \text { at } \\
1030^{\circ} \mathrm{C}\end{array}$ & $\begin{array}{c}\mathrm{Ni}-\mathrm{C}_{10} \mathrm{~S} \text { at } \\
1050^{\circ} \mathrm{C}\end{array}$ & Assignment & Reference \\
\hline \multirow{6}{*}{716} & \multirow{6}{*}{715} & & 676 & $\delta\left(\mathrm{SO}_{4}\right)$ & 25 \\
\hline & & 700 & & $v(\mathrm{C}-\mathrm{S})$ & 27 \\
\hline & & 749 & 740 & $\begin{array}{l}\mathrm{C}-\mathrm{H} \text { of } \\
\text { aromatic }\end{array}$ & 26 \\
\hline & & 803 & 794 & $\begin{array}{c}\mathrm{C}-\mathrm{H} \text { of } \\
\text { aromatic }\end{array}$ & 26 \\
\hline & & & 829 & $\begin{array}{l}\mathrm{C}-\mathrm{H} \text { of } \\
\text { aromatic }\end{array}$ & 26 \\
\hline & & & 922 & $v(\mathrm{Si}-\mathrm{OH})$ & 26 \\
\hline \multirow[t]{2}{*}{$\begin{array}{l}1023,1040, \\
1060,1116\end{array}$} & \multirow[t]{2}{*}{$\begin{array}{c}986,1020 \\
1047,1087, \\
1113\end{array}$} & \multirow[t]{2}{*}{$\begin{array}{c}997,1012, \\
1045,1067, \\
1112\end{array}$} & $\begin{array}{c}997,1043 \\
1090,1148 \\
1214\end{array}$ & $v\left(\mathrm{SO}_{4}\right)$ & 25 \\
\hline & & & 1343 & Aromatic rings & 26 \\
\hline \multirow[t]{2}{*}{1379} & \multirow[t]{2}{*}{1378} & \multirow[t]{2}{*}{1378} & \multirow{4}{*}{1406} & $\delta_{\mathrm{s}}\left(\mathrm{CH}_{3}\right)$ & $\begin{array}{c}22,23,24, \\
27\end{array}$ \\
\hline & & & & Aromatic rings & 26 \\
\hline 1415 & 1411 & 1416 & & $\delta_{\text {as }}\left(\mathrm{CH}_{2}\right)$ & 27,28 \\
\hline \multirow[t]{5}{*}{1465} & 1457 & 1461 & & $\delta_{\mathrm{s}}\left(\mathrm{CH}_{2}\right)$ & $22,23,27$ \\
\hline & 1531,1595 & 1536,1592 & 1608 & $v(-\mathrm{C}=\mathrm{C}-)$ & 20,21 \\
\hline & 1648 & 1648 & 1638 & $v\left(\mathrm{H}_{2} \mathrm{O}\right)$ & 25 \\
\hline & \multirow[t]{2}{*}{1693,1738} & \multirow[t]{2}{*}{1688,1741} & $\begin{array}{c}1679,1732 \\
1768\end{array}$ & $\begin{array}{c}v\left(-\mathrm{C}=\mathrm{C}=\mathrm{CH}_{2}\right) \\
\text { and } \\
v\left(>\mathrm{C}=\mathrm{C}=\mathrm{CH}_{2}\right)\end{array}$ & 20 \\
\hline & & & 1871,2001 & Aromatic rings & 26 \\
\hline
\end{tabular}

In a previous study [19] the authors have shown that the same type nickel powder, impregnated with n-decanethiol, is inactive for the steam reforming of methane, and this deactivation was found to be due to carbon deposition of the "unsaturated" type. These results corroborate with the above results to explain the high stability of the alkanethiolate SAMs adsorbed on Ni. In fact, the heating of the n-decanethiol-impregnated $\mathrm{Ni}$ powder up to $1030^{\circ} \mathrm{C}$ is characterized by the partial pyrolysis of the adsorbed layers. The pyrolysis proceeds through the creation of $\mathrm{C}_{\mathrm{x}} \mathrm{H}_{\mathrm{y}}$ species at the surface of the $\mathrm{Ni}$, precursors of $\mathrm{C}=\mathrm{C}$ and aromatic groups through dehydrogenation. The pyrolysis products more aggressively passivate the Ni surface because the double and aromatic bonds geometry allows the molecules to lie parallel to the surface and thereby deactivate it much more efficiently than the linear saturated thiols, anchored vertically on the Ni surface, 
are able to do. It is, thus, probable that the passivated Ni surface stabilizes and protects the adsorbed saturated carbon chains. These chains remain bonded to the surface until their cracking rate becomes significant at the higher temperatures, or until the passivation layer is removed, either through carbon diffusion into the interior $\mathrm{Ni}$ volume or, in the form of carbon monoxide, at the higher temperatures, when the gas reforming conditions are prevailing.

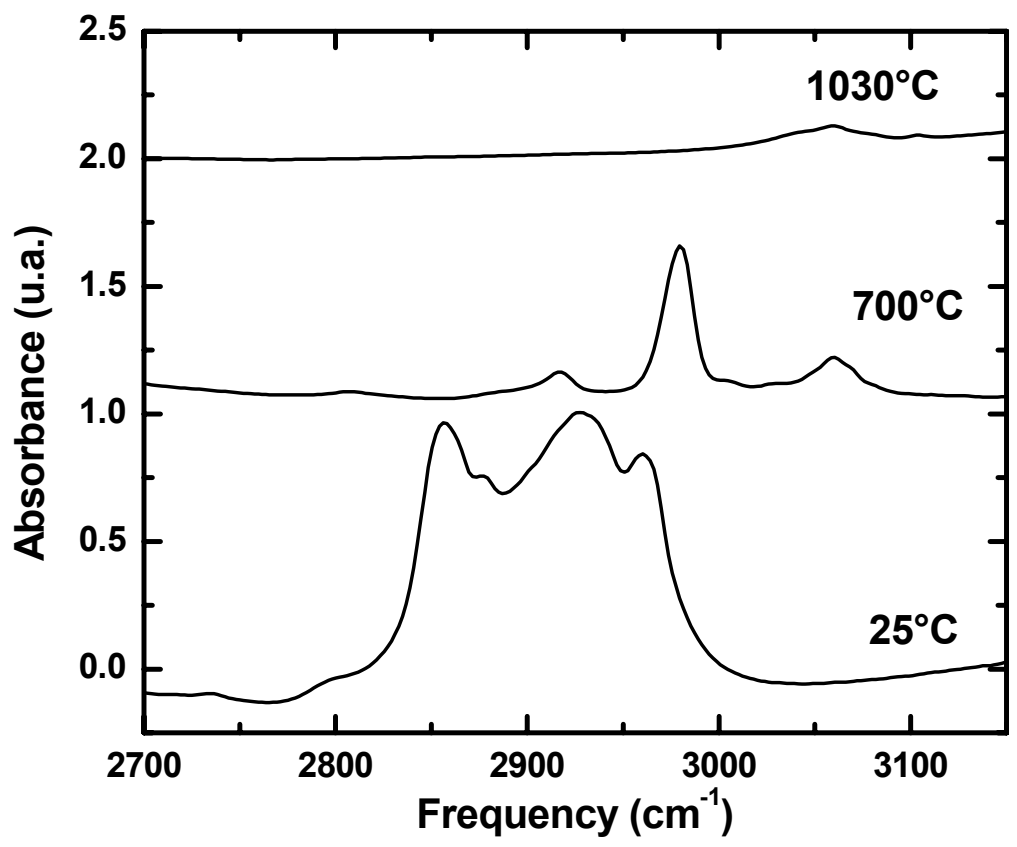

Figure 2: DRIFTS spectra of $\mathrm{SiO}_{2}-\mathrm{C}_{8}$ at high frequency recorded at three different temperatures, 23,700 , and $1030^{\circ} \mathrm{C}$.

Another experiment was carried out to demonstrate that nickel is responsible for the high stability of the alkanethiolate SAMs so adsorbed. Figure 2 presents representative IR spectra of commercial linear hydrocarbons bonded onto silica particles, $\left.\mathrm{SiO}_{2}-\mathrm{C}_{8}\left(-\mathrm{OSi}\left(\mathrm{CH}_{3}\right)_{2}\left(\mathrm{CH}_{2}\right)_{7} \mathrm{CH}_{3}\right)\right)$ recorded for samples thermally treated at three widely different temperatures, $23^{\circ} \mathrm{C}$ (starting material), $700^{\circ} \mathrm{C}$, and $1030^{\circ} \mathrm{C}$. All spectra were obtained at ambient temperature. The data recorded at $23^{\circ} \mathrm{C}$ shows the presence of the diagnostic $\mathrm{C}-\mathrm{H}$ stretching bands as characterized by the presence of three bands located at 2857, 2928, and $2962 \mathrm{~cm}^{-1}$. On annealing at $700^{\circ} \mathrm{C}$ under Ar carrier gas, the data shows the absence of all bands observed at $23^{\circ} \mathrm{C}$, in addition to new bands appearing at 2917,2980 , and $3060 \mathrm{~cm}^{-1}$. By continuing the heating up to $1030^{\circ} \mathrm{C}$ under $\mathrm{Ar}$ carrier gas, all the bands disappeared. The change recorded during the heating shows that the molecules adsorbed on silica were dissociated at a temperature lower than $700^{\circ} \mathrm{C}$. Saint-Pierre et al. [29] performed the TGA-MS method to determine the temperature stability of the organic phase bonded at the surface of silica particles $\left(\mathrm{SiO}_{2}-\mathrm{C}_{8}\right)$ and reported the decomposition commencing at $200^{\circ} \mathrm{C}$. 
These results confirm that the Ni powder surface used is responsible for the high stability of the alkanethiolate SAMs.

Thermally stable hydrocarbon species containing $\mathrm{sp}^{2}$ (up to $800^{\circ} \mathrm{C}$ ) carbons have been observed in the formation of silicon carbide layers on silicon [30]. Zahidi et al. [31] have demonstrated that thermal stability is compatible with a catalytically active surface for the formation of exceptionally stable alkylidenes on molybdenum carbide (up to $700^{\circ} \mathrm{C}$ ). Ding et al. [32] have shown that the aromatization of methane on the catalyst Mo/H-ZSN5 takes place at a temperature which varies between $680^{\circ}$ and $780^{\circ} \mathrm{C}$ after the transformation of Mo into molybdenum carbide during the period of induction of the catalyst. The carbidic carbon deposited on the catalyst passivates the surface against further carbon deposition through $\mathrm{CH} 4$ aromatization, but still allows the catalytic activation of $\mathrm{C}-\mathrm{H}$ bonds. Consequently, it has been shown that carbides can be accounted, at least partially, for the stability of adsorbed hydrocarbons layers. According to the literature [30-32] the carbides in general are effective substrates for the preparation of thermally stable hydrocarbon layers.

\section{Conclusion}

This work presents a new method for the preparation of thermally stable organic layers without the formation of carbides, and shows that thermal stability is compatible with a catalytically active surface. The high thermal stability of the Ni-alkanethiols surface presented in the study means that the so obtained organic layers may be used as spacer groups for high-temperature applications.

\section{Acknowledgements}

We gratefully acknowledge the financial support of this work by NSERC (Natural Sciences and Engineering Research Council) and the CFI (Canadian Foundation for Innovation).

\section{References}

[1] Crooks, R. M.; Ricco, A. J.; New Organic Materials Suitable for Use in Chemical Sensor Arrays, Acc. Chem. Res., 31, pp. 219-227, 1998.

[2] Wolkow, R. A.; Controlled Molecular Adsorption on Silicon: Laying a Foundation for Molecular Devices, Annu. Rev. Phys. Chem., 50, pp. 413441, 1999.

[3] Jeon, N. L.; Choi, I. S.; Whitesides, G. M.; Kim, N. Y.; Laibinis, P. E.; Harada, Y.; Finnie, K. R.; Girolami, G. S.; Nuzzo, R. G.; Patterned Polymer Growth on Silicon Surfaces Using Microcontact Printing and Surface-Initiated Polymerization, Appl. Phys. Lett., 75, pp. 4201-4203, 1999.

[4] Bain, C. D.; Troughton, E. B.; Tao, Y. T.; Evall, J.; Whitesides, G. M.; Nuzzo, R. G.; Formation of Monolayer Films by the Spontaneous 
Assembly of Organic Thiols from Solution onto Gold, J. Am. Chem. Soc., 111, pp. 321-335, 1989.

[5] (a) Ulman, A.; Formation and Structure of Self-Assembly Monolayers, Chem. Rev., 96, pp. 1533-1554, 1996. (b) Whitesides, G. M.; Ferguson, G. S.; Allara, D.; Scherson, D.; Speaker, L.; Ulman, A.; Organized Molecular Assemblies, Crit. Rev. Surf. Chem., 3, pp. 49-65, 1993. (c) Bain, C. D.; Evall, J.; Whitesides, G. M.; Formation of Monolayers by the Coadsorption of Thiols on Gold: Variation in the Head Group, Tail Group, and Solvent, J. Am. Chem. Soc., 111, pp. 7155-7164, 1989.

(d) Dubois, L. H.; Nuzzo, R. G. Synthesis, Structure, and Properties of Model Organic Surfaces, Annu. Rev. Phys. Chem., 43, pp. 437-463, 1992.

(e) Schriber, F. Structure and Growth of Self-Assembly Monolayers, Prog. Surf. Sci., 65, pp. 151-256, 2000.

[6] Somorjai, G. A. Introduction to Surface Chemistry and Catalysis 420 (John Wiley \& Sons, New York, (1994).

[7] Nozawa, K.; Aramaki, K. One- and Two-Dimensional Polymer Films of Modified Alkanethiol Monolayers for Preventing Iron from Corrosion, Corrosion Sci., 41, pp. 57-73, 1999.

[8] (a) Mekhalif, Z.; Riga, J.; Pireaux, J-J.; Delhalle, J. Self-Assembled Monolayers of $n$-Dodecanethiol on Electrochemically Modified Polycrystalline Nickel Surfaces, Langmuir, 13, pp. 2285-2290, 1997. (b) Mekhalif, Z.; Delhalle, J.; Pireaux, J.-J.; Noel, S.; Houe, F.; Boyer, L., Surface modifications of nickel substrates with self-assembled monolayers of alkanethiols for electrical contact applications, Surf. Coat. Technol., 100, pp. 463-468, 1998. (c) Mekhalif, Z.; Laffineur, F.; Couturier, N.; Delhalle, J., Elaboration of Self-Assembled Monolayers of n-Alkanethiols on Nickel Polycrystalline Substrates: Time, Concentration, and Solvent Effects, Langmuir, 19, pp. 637-645, 2003.

[9] (a) Mekhalif, Z.; Massi, L.; Guittard, F.; Geribaldi, S.; Delhalle, J., X-Ray photoelectron spectroscopy study of polycrystalline zinc modified by ndodecanethiol and 3-perfluorooctyl-propanethiol, Thin Solid Film, 405, pp. 186-193, 2002. (b) Sinapi, F.; Forget, L.; Delhalle, J.; Mekhalif, Z., Formation and characterization of thin films of $\mathrm{H}\left(\mathrm{CH}_{2}\right) \times \mathrm{PO}(\mathrm{OH})_{2}$ on polycrystalline zinc substrates, Surf. Interface Anal., 34, pp. 148-152, 2002. (c) Sinapi, F.; Forget, L.; Delhalle, J.; Mekhalif, Z., Self-assembly of (3-mercaptopropyl) trimethoxysilane on polycrystalline zinc substrates towards corrosion protection, Appl. Surf. Sci., 212, pp. 464-471, 2003.

[10] (a) Laffineur, F.; Delhalle, J.; Mekhalif, Z., Surface coating of a $\mathrm{Cu}-\mathrm{Ni}$ alloy with a self-assembled monolayer of n-dodecanethiol, Mater. Sci. Eng. C, 22, pp. 331-337, 2002. (b) Laffineur, F.; Couturier, N.; Delhalle, J.; Mekhalif, Z., Effect of the solvent on the formation of n-dodecanethiol films on a polycrystalline $\mathrm{Ag}_{90} \mathrm{Ni}_{10}$ substrate, Appl. Surf. Sci., 212, pp. 452-457, 2003.

[11] (a) K.D. Truong, P. Rowntree, Formation of Self-Assembled Butanethiol Monolayers on $\mathrm{Au}$ Substrates: Spectroscopic Evidence for Highly Ordered Island Formation in Sub-Monolayer Films, J. Phys. Chem., 100, 
pp. 19917-19926, 1996. (b) C. Chung, M. Lee, Exchange of selfassembled thiol monolayers on gold: characterization by FT-IR external reflection spectroscopy, Journal of Electroanalytical Chemistry, 468, pp. 91-97, 1999.

[12] (a) Han, S. W.; Kim, Y.; Kim, K.; Dodecanethiol-Derivatized Au/Ag Bimetallic Nanoparticles: TEM, UV/VIS, XPS, and FTIR Analysis, J. Colloid Interface Sci., 208, pp. 272-278, 1998. (b) Hostetler, M. J.; Stokes, J. J.; Murray, W.; Infrared Spectroscopy of Three-Dimensional Self-Assembled Monolayers: $N$-Alkanethiolate Monolayers on Gold Cluster Compounds, Langmuir, 12, pp. 3604-3612, 1996.

[13] (a) Han, S. W.; Lee, S. J.; Kim, K.; Self-Assembled Monolayers of Aromatic Thiol and Selenol on Silver: Comparative Study of Adsorptivity and Stability, Langmuir, 17, pp. 6981-6987, 2001. (b) Kim, J.; Koel, B. E.; TPD and FT-IRAS Investigation of Ethylene Oxide (EtO) Adsorption on an $\mathrm{Au}(211)$ Stepped Surface, Langmuir, 21, pp. 3886-3891, 2005.

[14] Nuzzo, R. G.; Zegarski, B. R.; Dubois, L. H., Fundamental studies of the chemisorption of organosulfur compounds on gold(111). Implications for molecular self-assembly on gold surfaces, J. Am. Chem. Soc., 109, pp. 733-740, 1987.

[15] Jaffey, D. M.; Madix, R. J., Reactivity of Sulfur-Containing Molecules on Noble Metal Surfaces. 2. tert-Butyl Thioalcohol on Au(110), J. Am. Chem. Soc., 116, pp. 3012-3019, 1994.

[16] Schlenoff, J. B.; Li, M.; Ly, H., Stability and Self-Exchange in Alkanethiol Monolayers, J. Am. Chem. Soc., 117, pp. 12528-12536, 1995.

[17] Lai, Y. H.; Yeh, C. T.; Cheng, S. H.; Liao, P.; Hung, W. H.; Adsorption and Thermal Decomposition of Alkanethiols on $\mathrm{Cu}(110)$, J. Phys. Chem. B., 106, pp. 5438-5446, 2002.

[18] Lin, T. H.; Huang, T. P.; Liu, Y. L.; Yeh, C. C.; Lai, Y. H.; Hung, W. H.; Adsorption and Thermal Reactions of Alkanethiols on $\operatorname{Pt}(111)$ : Dependence on the Length of the Alkyl Chain, J. Phys. Chem. B., 109, pp. 14079-14084, 2005.

[19] Rakass S., Oudghiri-Hassani H., Abatzoglou N., Rowntree P., A Study of the Surface Properties and Steam Reforming Catalytic Activity of Nickel Powders Impregnated by n-Alkanethiols J. Power. Sources, 162, pp. 579$588,2006$.

[20] Paronen, M.; Sundholm, F.; Ostrovskii, D.; Jacobsson, P.; Jeschke, G.; Rauhala, E.; Tikkanen, P.; Preparation of Proton-Conducting Membranes by Direct Sulfonation. 1. Effect of Radicals and Radical Decay on the Sulfonation of Poly(vinyl fluoride) Films, Chem. Mater., 15, pp. 4447-4455, 2003.

[21] Lazar, G.; Lazar, I.; IR characterization of a-C:H:N films sputtered in $\mathrm{Ar} / \mathrm{CH}_{4} / \mathrm{N}_{2}$ plasma, Journal of Non-crystalline Solids, 331, pp. 70-78, 2003.

[22] Nuzzo, R. G.; Korenic, E. M.; Dubois, L. H.; Studies of the temperaturedependent phase behavior of long chain $n$-alkyl thiol monolayers on gold, J. Chem. Phys., 93, pp. 767-773, 1990. 
[23] Nuzzo, R. G.; Dubois, L. H.; Allara, D. L.; Fundamental studies of microscopic wetting on organic surfaces. 1. Formation and structural characterization of a self-consistent series of polyfunctional organic monolayers, J. Am. Chem. Soc., 112, pp. 558-569, 1990.

[24] Boiadjiev, V.; Blumenfeld, A.; Gutow, J.; Tysoe, W. T.; Infrared and NMR Spectroscopic Studies of n-Alkanethiols Chemically Grafted on Dimethylzinc-Modified Silica Surfaces, Chem. Mater., 12, pp. 2604-2613, 2000.

[25] Petrosyants, S. P.; Ilyukhin, A. B.; Sukhorukov, A. Y.; Coordination Polymers of Scandium Sulfate Crystal Structure of $\left(\mathrm{H}_{2} \mathrm{Bipy}\right)$ $\left[\mathrm{Sc}\left(\mathrm{H}_{2} \mathrm{O}\right)\left(\mathrm{SO}_{4}\right)_{2}\right]_{2} \quad 2 \mathrm{H}_{2} \mathrm{O}$ and $\left(\mathrm{H}_{2} \mathrm{Bipy}\right) \quad\left[\mathrm{HSO}_{4}\right]_{2}$, Russian Journal of Coordination Chemistry, 31, pp. 545-551, 2005.

[26] Onida, B.; Borello, L.; Busco, C.; Ugliengo, P.; Goto, Y.; Inagaki, S.; Garrone, E.; The Surface of Ordered Mesoporous Benzene-Silica Hybrid Material: An Infrared and ab initio Molecular Modeling Study, J. Phys. Chem. B., 109, pp. 11961-11966, 2005.

[27] Hostetler, M. J.; Stokes, J. J.; Murray, R. W.; Infrared Spectroscopy of Three-Dimensional Self-Assembled Monolayers: N-Alkanethiolate Monolayers on Gold Cluster Compounds, Langmuir, 12, pp. 3604-3612, 1996.

[28] Smith, E. L.; Porter, M.D.; Structure of monolayers of short chain nalkanoic acids $\left(\mathrm{CH}_{3}\left(\mathrm{CH}_{2}\right)_{\mathrm{n}} \mathrm{COOH}, \mathrm{n}=0-9\right)$ spontaneously adsorbed from the gas phase at silver as probed by infrared reflection spectroscopy, J. Phys. Chem. 97, pp. 8032-8038, 1993.

[29] Saint-Pierre, G.; Changes, A.; Bouchard, N. A.; Harvey, P.; Brossard, L.; Ménard, H.; Rational Design of Original Materials for the Electrocatalytic Hydrogenation Reactions: Concept, Preparation, Characterization, and Theoretical Analysis, Langmuir, 20, pp. 6365-6373, 2004.

[30] Park, S. -C.; Kang, H.; Lee, S. B.; Reaction intermediate in thermal decomposition of 1,3-disilabutane to silicon carbide on $\mathrm{Si}(111)$ : Comparative study of $\mathrm{Cs}^{+}$reactive ion scattering and secondary ion mass spectrometry, Surf. Sci., 450, pp. 117-125, 2000.

[31] Zahidi, E. M.; Oudghiri-Hassani, H; McBreen, P. H.; Formation of thermally stable alkylidene layers on a catalytically active surface, Nature, 409, pp. 1023-1026, 2001.

[32] Ding, W.; Li, S.; Meitzner, G. D.; Iglesia, E.; Methane Conversion to Aromatics on Mo/H-ZSM5: Structure of Molybdenum Species in Working Catalysts, J. Phys. Chem. B., 105, pp. 506-513, 2001. 